\title{
Fognyúlvány mikroszkóppal asszisztált reszekciója submandibularis retropharyngealis „key-hole” behatolásból
}

\author{
Süvegh Dávid oh. ${ }^{1}$ - Viola Árpád dr. ${ }^{2}$ \\ ${ }^{1}$ Semmelweis Egyetem, Budapest \\ ${ }^{2}$ Semmelweis Egyetem, Neurotraumatológiai Tanszéki Csoport, \\ Péterfy Kórház-Rendelőintézet és Manninger Jenő Országos Traumatológiai Intézet, \\ Idegsebészeti és Neurotraumatológiai Osztály, Budapest
}

\begin{abstract}
Célunk egy új műtéti eljárás, a mikroszkóp asszisztálta submandibularis retropharyngealis densnyúlvány reszekciójának bemutatása „key-hole” behatolásból. Páciensünk motorbaleset kapcsán szenvedte el a CII. nyakcsigolya fognyúlványtörését. Eltávolítottuk a CII. nyakcsigolya densnyúlványának felső kétharmadával együtt a nyúltvelői kompreszsziót okozó corticalis fragmentumot. Ennél a mútéti eljárásnál elkerülhető a hagyományos transoralis behatoláskor előforduló velopharyngealis elégtelenség, ugyanakkor biztosított a densnyúlványhoz való hozzáférés. Az új eljárás mellett szólt az MR-vizsgálattal igazolt ventralis dúrasérülés, amely a transoralis feltáráskor előforduló velopharyngealis elégtelenség magas kockázatával együtt növeli a sebgyógyulási zavar és a szeptikus állapot előfordulását. A submandibularis „key-hole” technika során szövetragasztó mellett több rétegben volt lehetőség vitális lágy részekkel tamponálni a dúrasérülés helyét. A mikroszkóp asszisztálta submandibularis „key-hole” műtéti eljárást követően elvégzett posztoperatív CT- és MR-vizsgálat visszaigazolta a nyúltvelő teljes dekompresszióját. A páciens tetraplegiás neurológiai állapota teljes mértékben regrediált. Nyolc hónappal a mútétet követően a páciens önellátó. Az általunk alkalmazott technika a továbbiakban mérlegelendő alternatívaként szolgálhat a klasszikus, transoralis transpharyngealis vagy endoszkópos endonasalis densreszekcióval szemben.
\end{abstract}

Orv Hetil. 2020; 161(31): 1302-1306.

Kulcsszavak: submandibularis, retropharyngealis, densreszekció

\section{Microscope-assisted odontoid resection via submandibular retropharyngeal "key-hole" approach}

Our objective is to propose a novel surgical technique, the microscope-assisted odontoid resection via submandibular retropharyngeal "key-hole" approach. The patient suffered a traumatic cervical spine injury due to a motorcycle accident. We removed the upper two-thirds of the CII vertebra's odontoid process along with the cortical fragment causing the medullar compression. With this surgical technique the velopharyngeal insufficiency, occurring at the traditional transoral surgery, is avoidable while the access to the odontoid process is insured. The MRI confirmed ventral injury to the meninges, which increases the risk of wound healing complications and sepsis so along with the high risk of velopharyngeal insufficiency occurring at the transoral surgery, stood in favour of the new method. During the submandibular "key-hole" technique besides the use of tissue-glue, tamponing the meninges damage with multiple layers of viable soft tissue could be performed. The postoperative CT and MR imaging confirmed the complete decompression of the medulla oblongata. The patient's tetraplegic state entirely regressed, and eight months after the surgery he became self-sufficient. From now on, the surgical method we used could be a considerable alternative to the classic transoral transpharyngeal or endoscopic endonasal odontoid resection.

Keywords: submandibular, retropharyngeal, odontoid resection

Süvegh D, Viola Á. [Microscope-assisted odontoid resection via submandibular retropharyngeal "key-hole" approach]. Orv Hetil. 2020; 161(31): 1302-1306.

(Beérkezett: 2020. március 8.; elfogadva: 2020. április 1.) 


\section{Rövidítések}

ASIA = (American Spinal Injury Association Impairment Scale $)$ Amerikai Gerincsérülés Egyesület Értékvesztési Skála; CT = (computed tomography) számítógépes tomográfia; $\mathrm{MR}=$ (magnetic resonance) mágneses rezonancia; USA = (United States of America) Amerikai Egyesült Államok

A craniocervicalis átmenet egy komplex régió, sajátos anatómiai és funkcionális kapcsolatokkal. A második nyakcsigolya densnyúlványát érintő patológiák sebészi kezelése gyakran megköveteli a dorsalis és ventralis dekompressziót, beleértve a dens reszekcióját is [1]. A dekompressziót követő rögzítés szükségességéről az adott eset klinikai és anatómiai sajátosságai alapján döntünk [2]. A ventralis dekompresszió legelterjedtebb formája a transoralis transpharyngealis feltárásból történő densnyúlvány-eltávolítás [3], mely a mútéti terület növelésére kiegészíthető Le Fort- vagy transmandibularis osteotomiával [4]. A ventralis cervicomedullaris kompresszió kezelésének legújabb módszere az endoszkópos endonasalis densreszekció [5], melynek előnye a hagyományos eljárással szemben [2], hogy a kemény és lágy szájpad megőrzése drasztikusan csökkenti a velopharyngealis elégtelenség kockázatát, ugyanakkor direkt hozzáférést enged a densnyúlványhoz [5].

$\mathrm{Az}$ anterior transcervicalis retropharyngealis módszerrel elkerülhetôk a transmucosalis eljárások komplikációi és korlátai. Míg a standard Smith-Robinson-módszerrel a CIII. csigolya és porckorong szintjének elérése nem minden esetben megoldott, az anterior retropharyngealis módszerrel a teljes nyaki gerinc megközelíthető [6]. A transcervicalis módszer esetében azonban számolni kell a mély mútéti tér és a meredek elérési szög okozta nehézségekkel [7]. A magas anterior transcervicalis eljárás széles hozzáférést enged a felső nyaki gerincszakaszhoz dekompresszió és fúzió céljából egyaránt [8]. A transoralis, transnasalis és retropharyngealis feltárásnál az eltérő hozzáférési útból és szögből adódóan a megfelelő módszert az adott eset anatómiai és patológiai sajátosságainak ismeretében célszerú kiválasztani [9].

\section{Módszer}

A 44 éves férfi páciens motorkerékpárosként szenvedte el a CII. nyakcsigolya densnyúlványának AndersonD’Alonso II. típusú, dislocatio nélküli, CT-vizsgálattal igazolt törését, melynek kapcsán a densnyúlvány dorsalis corticalis rétege $17 \mathrm{~mm}$ hosszan leszakadt, $\mathrm{s}$ dúrát sértve a nyúltvelőn bal oldali túlsúllyal benyomatot okozott (1. ábra). A páciens nyaki gerincét 'stiff-neck' ortézissel rögzítettük. Az elvégzett akut MR-vizsgálat a kiszakadt csontlemez és a densnyúlvány között térszúkítő haematomát, liquordenzitást és a hátsó szalagrendszer sérülését mutatta (2.ábra). A páciens neurológiai statusában tetraplegiás állapotot észleltünk; az American Spinal Injury Association Impairment Scale (a továbbiakban: ASIA) szerinti értéke a kórházba szállításkor a páciens kooperációjának hiányában, gépi lélegeztetés mellett nem volt megítélhető. A páciensnél sürgősséggel dorsoventralis dekompressziót és stabilizálást terveztünk. Első lépésben hason fekvő helyzetben a páciens fejét MAYFIELD fejtartóban (Integra LifeSciences, Plainsboro, NJ, USA) rögzítettük. Hátsó feltárásból CI.-CII. csavaros fúziót, a nyúltvelő tehermentesítésére a CI. csigolya hátsó ívének

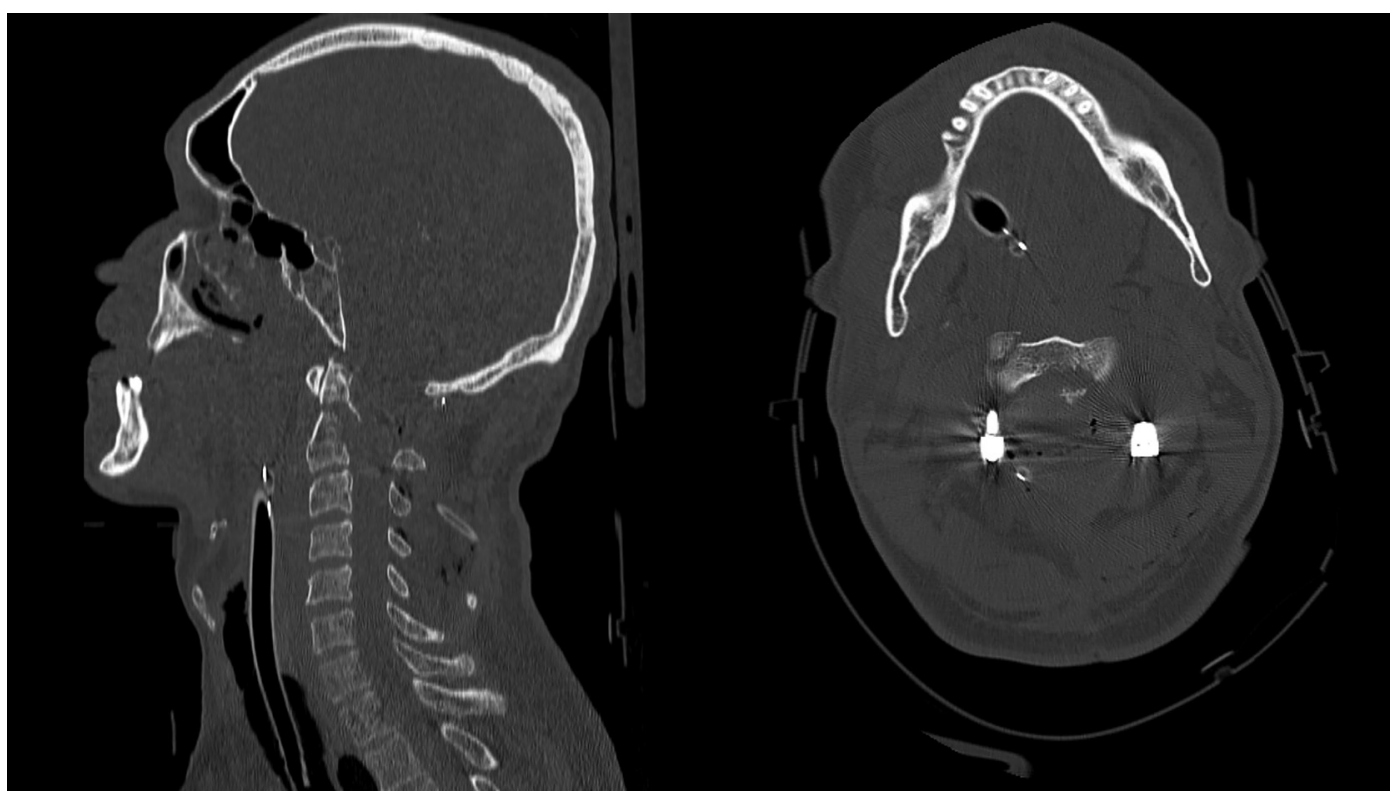

1. ábra

Mútét előtti CT - densnyúlvány dorsalis corticalis rétege okozta nyúltvelői kompresszió (a kép a dorsalis dekompresszió után és a ventralis mútét előtt készült)

CT = számítógépes tomográfia 


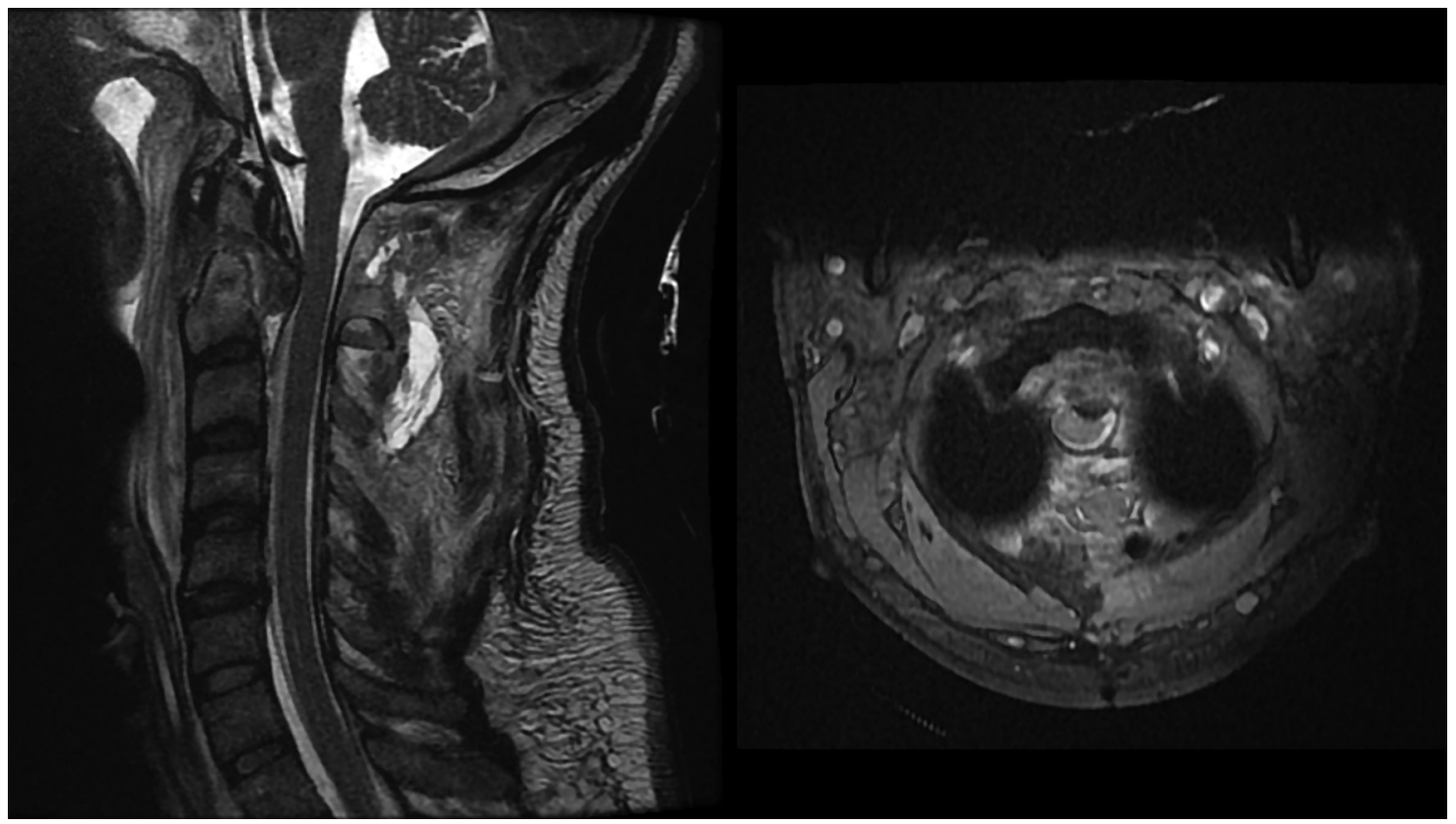

2. ábra

Mútét előtti MR - densnyúlvány körüli térszúkító haematoma, liquordenzitás és a hátsó szalagrendszer sérülése (a kép a dorsalis dekompresszió
után és a ventralis mútét előtt készült)
MR = mágneses rezonancia

eltávolítását végeztük el. A páciens instabil keringésére való tekintettel a nyúltvelő ventralis dekompresszióját nem tudtuk sürgősséggel elvégezni. A posztoperatív 3. napra a páciens neurológiai statusában jelentős javulást észleltünk, az addigi tetraplegiás állapot súlyos, alsó végtagi túlsúlyú tetraparesisre mérséklődött. A gerincvelői perfúzió biztosítása céljából keringéstámogatást - noradrenalinadást igényelt. A páciens keringési instabilitásával párhuzamosan neurológiai állapota a posztoperatív 6. napig javult, ezért a ventralis dekompressziót célzó mútétet elhalasztottuk. A páciensnek a posztoperatív 6. napon észlelt neurológiai statusa a következőt mutatta: a jobb kezével szorítani tudott, a jobb bicepsszel 3/5-ös, a tricepsszel 3/5-ös, a deltaizomban 2/5-ös, a trapézizomban 3/5-ös izomereje volt, a bal tricepszben és bicepszben kontrakciói voltak, ugyanakkor az alsó végtagokban nem volt kontrakció. Érdemi kooperáció hiányában érzészavart nem tudtunk vizsgálni.

A páciens neurológiai állapotában a posztoperatív 7. napon hirtelen visszaesés állt be, a kezdeti tetraplegiához közeli állapotot észleltünk. Ekkor a nyúltvelő ventralis dekompressziója mellett döntöttünk. Az egyébként is magas liquorszivárgás-kockázattal járó transoralis densreszekció helyett az MR-vizsgálattal igazolt dúrasérülésre való tekintettel submandibularis feltárást és ebből történő densreszekciót választottunk. A submandibularis feltárás a lágy részekkel történő tamponálás lehetőségével a liquorszivárgás kockázatát csökkenti [3-6]. SynFrame (Synthes, West Chester, PA, USA) karbonszálas feltáróval mikroszkóp asszisztálta ventralis submandibularis feltárásból elvégeztük a densnyúlvány középső harmadának, valamint a nyúltvelői kompressziót okozó haematomának és corticalis csontfragmentumnak az eltávolítását. A mútét során a corticalis csontfragmentum okozta durasérülést feltártuk, azt sikerrel tamponáltuk. A posztoperatív CT- és MR-vizsgálat a nyúltvelő teljes körû dekompresszióját mutatta (3. és 4. ábra). A ventralis submandibularis behatolásból történt nyúltvelői dekompressziót követő 2 . napon a páciens addigi, súlyos fokú tetraparesise alsó végtagi túlsúlyú, közepes fokú paraparesissé javult. A 2. mütétet követő 2. napon a páciens kooperációjával rögzített ASIA-érték 142/324, a 13. és 19. napon mért ASIA-érték 280/324, illetve 290/324 volt. A rehabilitáció során, a 2. mütéttől számított 127. napon az ASIA-érték 298/324 volt.

\section{Megbeszélés}

A második nyakcsigolya densnyúlványának AndersonD’Alonso II. típusú törése nem számít ritka nyakigerincsérülésnek. Az esetünkben bemutatott, a dorsalis corticalis csontlemeznek a CII. nyakcsigolya densnyúlványa elmozdulás nélküli törését kísérő leválását és a csontlemez okozta nyúltvelői kompressziót bemutató közleményt nem találtunk. Az első lépésben a nyaki gerinc sagittalis profiljának biztosítása céljából [10] dorsalis CI.-CII. fúziót végeztünk.

A második lépésben két lehetőséget mérlegeltünk: 1) transoralis densreszekció vagy 2) submandibularis retropharyngealis feltárásból történő densnyúlvány-reszekció $[8,11,12]$. Mivel a transoralis densreszekció esetében magasabb a kockázata a liquorszivárgás szövődményének [6], esetünkben, amikor az MR-vizsgálat igazol- 


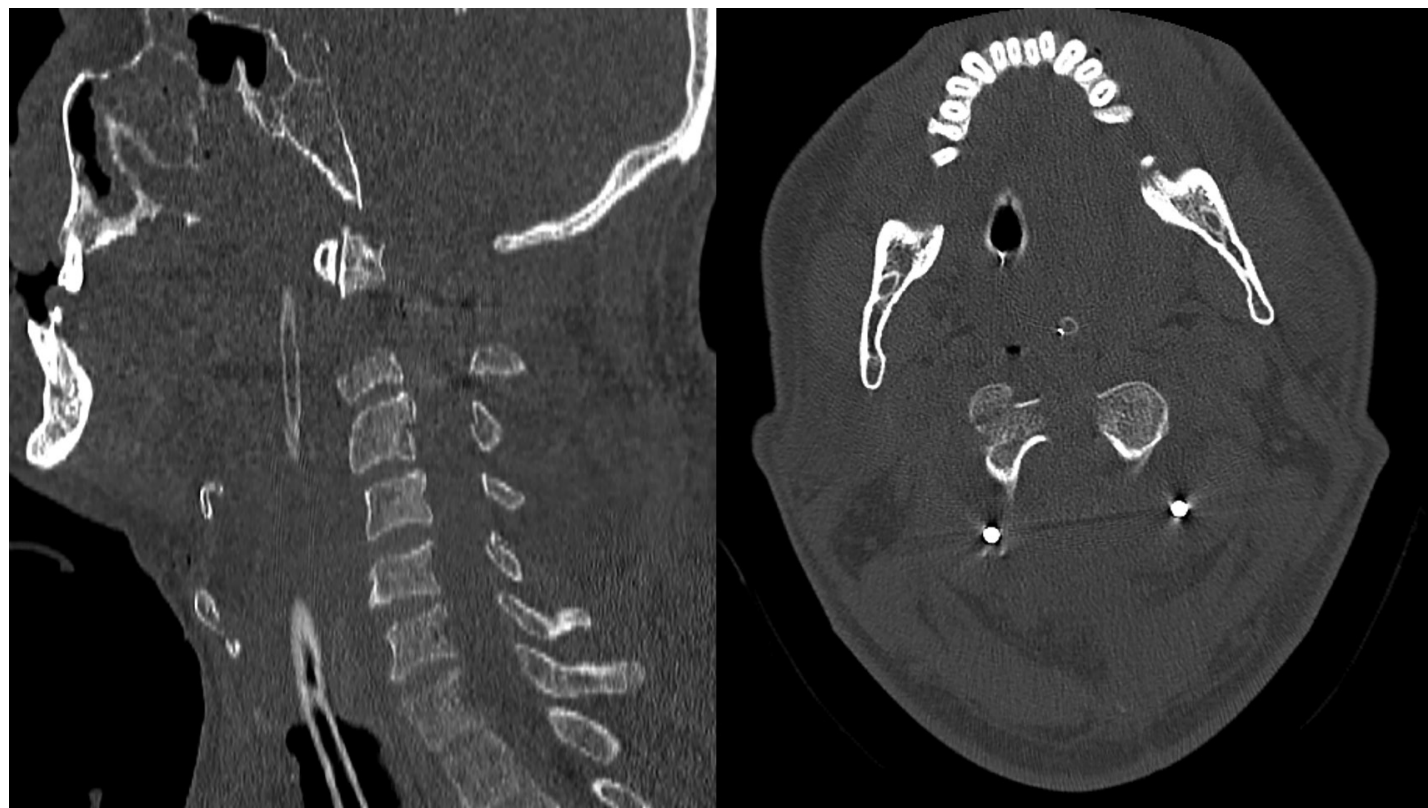

3. ábra

| Mútét utáni CT - csontos dekompresszió, ventralis dekompresszió után

$\mathrm{CT}$ = számítógépes tomográfia

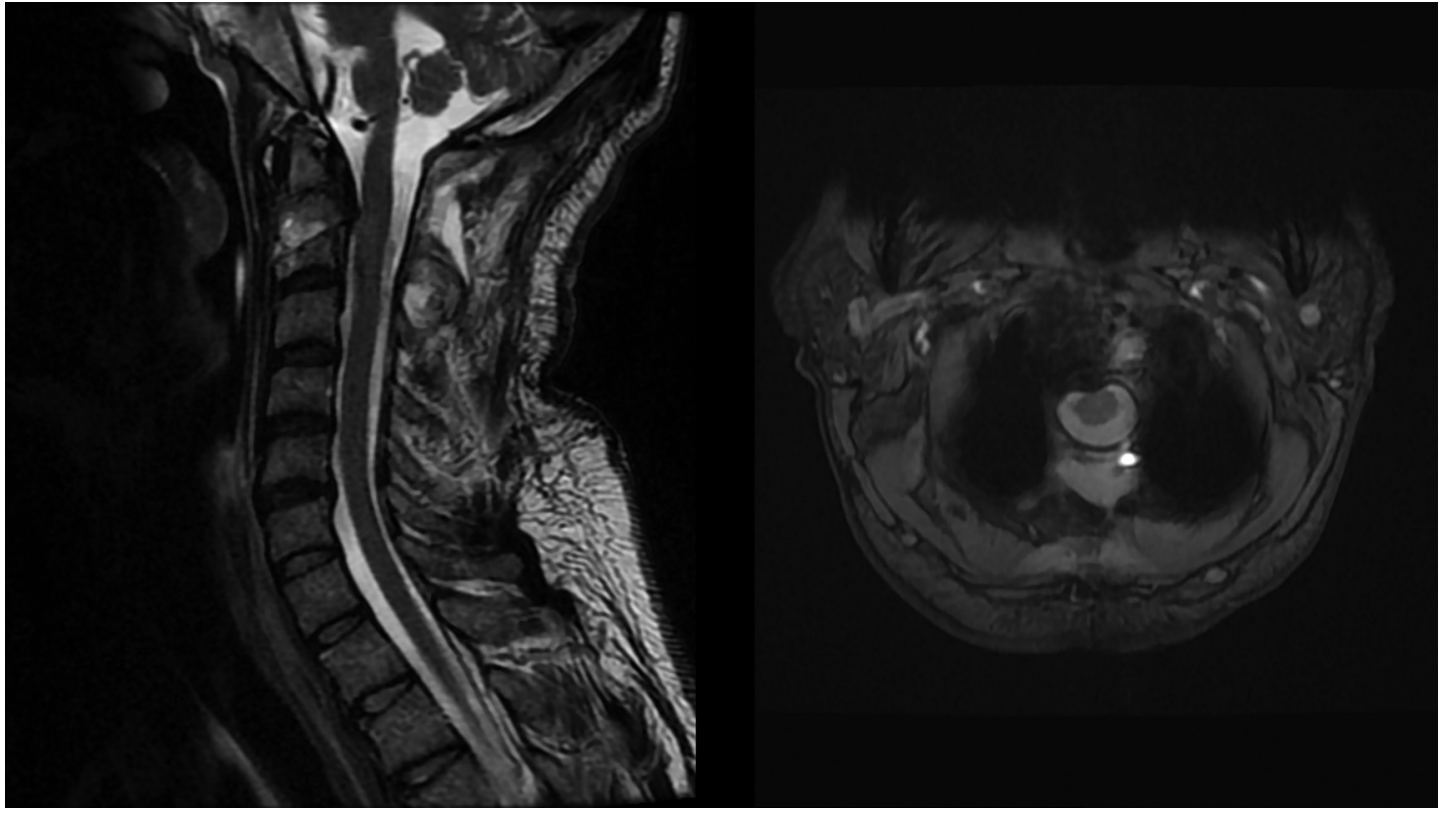

4. ábra

Műtét utáni MR - nyúltvelői dekompresszió, ventralis dekompresszió után

$\mathrm{MR}=$ mágneses rezonancia

ta a dúrasérülést (2. ábra), a submandibularis feltárás mellett döntöttünk, csökkentve a posztoperatív liquorszivárgás kockázatát. A submandibularis feltárás során szövetragasztó mellett több rétegben van lehetőség vitális lágy részekkel tamponálni a dúrasérülés helyét. Mivel a dorsalis corticalis csontlemez okozta nyúltvelői kompresszió bal oldali túlsúlyú volt (2. ábra), a jobb oldali submandibularis retropharyngealis feltárás jobb lehetőséget biztosított a dekompresszióra.

\section{Következtetés}

Ahogy azt az általunk referált eset is mutatja, mindig célszerú az adott patológiához igazítani a mütéti sorrendnek és a behatolás módjának kiválasztását, esetünkben: 1) a sagitalis profil biztosítása dorsalis CI.-CII. fúzióval, 2) jobb oldali submandibularis retropharyngealis dekompresszió és a liquorszivárgás ellátása - tamponálása szövetragasztóval és lágy részekkel. 
Anyagi támogatás: A közlemény megírásáért a szerzők anyagi támogatásban nem részesültek.

Szerzői munkamegosztás: S. D.: Az elvégzett mütét során asszisztens volt, irodalmi háttérkutatást végzett, a cikkben szereplő képeket készítette, valamint az irodalmi hivatkozások beillesztését, az absztrakt angol nyelvre történő fordítását, a cikk irodalmi áttekintését taglaló rész, valamint a megbeszélés megírását végezte. V. Á.: Az első szerző munkájának vezetését, tutorálását, a mütét végrehajtását, valamint a cikk végleges formájának kialakítását és ellenőrzését végezte. A cikk végleges változatát mindkét szerző elolvasta és jóváhagyta.

Érdekeltségek: A szerzőknek nincsenek érdekeltségeik.

\section{Irodalom}

[1] Shriver MF, Kshettry VR, Sindwani R, et al. Transoral and transnasal odontoidectomy complications: a systematic review and meta-analysis. Clin Neurol Neurosurg. 2016; 148: 121-129.

[2] Yu Y, Hu F, Zhang X, et al. Endoscopic transnasal odontoidectomy. Sports Med Arthrosc Rev. 2016; 2: 2-6.

[3] Iacoangeli M, Di Rienzo A, Colasanti R, et al. Endoscopic transnasal odontoidectomy with anterior $\mathrm{Cl}$ arch preservation and anterior vertebral column reconstruction in patients with irreducible bulbomedullary compression by complex craniovertebral junction abnormalities: operative nuance. Oper Neurosurg (Hagerstown). 2016; 12: 222-230.
[4] Ishida W, McCormick KL, Lo S. Craniocervical approach: transcervical. In: Sciubba DM. (ed.) Spinal tumor surgery. Springer, Cham, 2019; pp. 29-41.

[5] Zoli M, Mazzatenta D, Valluzzi A, et al. Endoscopic endonasal odontoidectomy. Neurosurg Clin N Am. 2015; 26: 427-436.

[6] Hodges SD, Humphreys SC, Brown TW Jr, et al. Complications of the anterior retropharyngeal approach in cervical spine surgery: a technique and outcomes review. J South Orthop Assoc. 2000; 9: 169-174.

[7] Wang B, Lü G, Deng Y, et al. Anterior endoscopically assisted transcervical reconstruction of the upper cervical spine. Eur Spine J. 2011; 20: 1526-1532.

[8] Park SH, Sung JK, Lee SH, et al. High anterior cervical approach to the upper cervical spine. Surg Neurol. 2007; 68: 519-524.

[9] Ruetten S, Hahn P, Oezdemir S, et al. Full-endoscopic uniportal retropharyngeal odontoidectomy for anterior craniocervical infection. Minim Invasive Ther Allied Technol. 2019; 28: 178185.

[10] Elbadrawi AM, Elkhateeb TM. Transoral approach for odontoidectomy efficacy and safety. HSS J. 2017; 13: 276-281.

[11] Feng L, Wei X, Fan Z, et al. Video-assisted high anterior transcervical approach for spinal lesions of the craniovertebral junction. Chin J Orthop. 2011; 31: 213-218.

[12] Ricciardi L, Sturiale CL, Izzo A, et al. Submandibular approach for single-stage craniovertebral junction ventral decompression and stabilization: a preliminary cadaveric study of technical feasibility. World Neurosurg. 2019; 127: 206-212.

(Viola Árpád dr., Budapest, Fiumei út 17., 1087 e-mail: arpadviola@gmail.com)

\section{"Numquam non miser est qui quod timeat cogitat." (Sosem elégedett, aki csak félelmeire gondol.)}

A cikk a Creative Commons Attribution 4.0 International License (https://creativecommons.org/licenses/by/4.0/) feltételei szerint publikált Open Access közlemény, melynek szellemében a cikk bármilyen médiumban szabadon felhasználható, megosztható és újraközölhető, feltéve, hogy az eredeti szerző és a közlés helye, illetve a CC License linkje és az esetlegesen végrehajtott módosítások feltüntetésre kerülnek. (SID_1) 